\title{
Research on the Protection Mechanism of the Party Building in Rural Areas from the Perspective of Governing Ethics
}

\author{
Baoquan $\mathrm{Hao}^{1}$ \\ ${ }^{1}$ School of Marxism, Northwestern Polytechnical University, Xi'an, China \\ Correspondence: Baoquan Hao, School of Marxism, Northwestern Polytechnical University, Xi'an 710072, \\ China. Tel: 180-9256-9559. E-mail: zxw_bq@hotmail.com
}

Received: December 11, 2017

Accepted: December 28, 2017 Online Published: January 9, 2018

doi:10.5539/jpl.v11n1p10

URL: https://doi.org/10.5539/jpl.v11n1p10

\begin{abstract}
Governing ethics act as the moral basis for the political authority of the governing Party and the value guidance of the behaviors of the governing Party and its members. Community-level Party organizations, playing a key role in the work of the Communist Party of China (CPC) in rural areas, are the basic platforms for rural Party members to be acknowledged and respected. The building of them has always been highly emphasized by the Party. However, the key role of community-level Party organizations in rural areas has been weakened to some extent by the increasing amount of rural Party members joining the floating population, the negative effect of pan-market phenomenon in the whole society, and the hollowing condition caused by the floating away of population in the under-developed rural areas, which all have added up a critical problem hindering the building of governing ethics of the Party in the rural areas. Thus, this paper proposes a comprehensive protection mechanism which is constituted by five steps as the standard for the building of community-level Party organizations in rural areas, a stimulus for the effective restoration of the role of community-level Party organizations in rural areas in enhancing the development of rural economy, serving people, rallying public support and promoting harmony, and a choice for community-level Party organizations in rural areas to regain their function and subjective position in the vision of governing ethics.
\end{abstract}

Keywords: governing ethics, rural party members, subjective position, protection mechanism

\section{Introduction}

The building of community-level Party organizations is a permanent strategy, which needs continuous practice, perfection, and improvement. The community-level Party organizations in rural areas therefore need unremitting efforts in its building to reach a new level in governance. The building of community-level Party organizations in rural areas and the subjective position of rural Party members have always been a great concern of the Chinese communists since the founding of PRC had benefited too much from the path of encircling the cities from rural areas. The mismatching between the original governing model of community-level Party organizations in rural areas and the new economic and social condition in rural areas, between the leading method of Party organizations and the framework of farmers' self-administration, and between the Party community-level democracy and the subjective position of farmers, which all embody the deep changes in the social structure and pattern of interests and benefits in rural areas with the accelerating of the process in the building of political democracy and the economic and social development in rural areas, have not only brought a great change in people's views and values, their life styles, and the general atmosphere in society, but also some challenges for the building of community-level Party organizations in rural areas. Confronted with this challenge, an seemingly omnipotent theory__ "Two Back-feedings" or "Two Supports" though put forward to deal with the issues relating to agriculture, rural areas and farmers in the Chinese academic circles, has been proved to be less effective, no matter it is about the support of industry to agriculture or the support of cities to rural areas. The solving of the problems has to rely on the motivation of farmers' enthusiasm, initiative and creativity, the full play of rural Party members' subjective position and function, and the re-recognition of the significance of governing ethics over the building of community-level Party organizations by the community-level Party organizations themselves, because governing ethics are the moral basis for governing authority of the governing Party. They act as the value guidance for the behaviors of the governing Party and its members. Above all, the community-level Party organizations should respond to the Party's call of "making the community-level Party 
organizations more service-oriented, with serving the people and engaging in people-related work being their main tasks," by protecting the subjective position of Party members through promoting Party democracy, and showing the Party members care and love from the stance of the Party, which will surely increase the belongingness of Party members, and the cohesiveness and attraction of the Party.

\section{The Governing Function of Community-Level Party Organizations and the Subjective Position of Its Members in Rural Areas from the Perspective of Governing Ethics}

In terms of the political, economical and cultural changes in the rural areas in the new period of time, the community-level Party organizations should purposefully and comprehensively adjust and reform their power structure, organization, members' value, positioning of role, the relationship with other social organizations in rural areas, etc. to adapt to the changes in and out of the Party organizations and the tasks on them, because they can only radiate new vitality and play an active role in the new situation by adapting to the changes, conforming to the situation and innovating. And it is actually the new changes of the social situation that bring about the logical starting point of the innovation of the governance of community-level Party organizations.

Any kind of political system and political behavior must have some kind of ethics as its value guidance, and any party will uphold ethical values it considers reasonable. The Chinese communists believe that the pursuit of governing ethics which comprise all the publicly recognized ethical beliefs and norms which have been formed in the Party's governing practice and have been followed by the Party at the same time is reasonable and proper. The ethics can stipulate the governing process, governing behavior, governing result, etc. of the governing Party, and can be an authoritative model to measure the behaviors of all the members of society. The contemporary integration of rule of law and rule of virtue in China to build a socialist country based on rule of law reflects the high importance the CPC attaches to the building of governing ethics in the process of the building of a law-based country. According to Genetic Theory, virtue came into existence before law, and some virtually "should" have become legally "must" which caters for the practical requirements of society as the time goes by. The building of governing ethics focuses on people's motivational civilization and self-discipline, as well as the raising of moral recognition and self-consciousness, which plays a key role in alleviating social conflicts and mediating all kinds of social relations.

In essence, the system of ethics is a system of rules offering ethical concepts, which should be followed in dealing with people-to-people and people-to-society relations. It is also a kind of metaphysical meditation of moral phenomenon. Subjective position is a kind of social status while subjectivity represents the capability for occupying this status. Ethics are the basic moral codes people have to follow in dealing with their rights and obligations, and so can be displayed in their behaviors and wills. The protection of Party members' subjective position and the raising of their subjectivity promote each other and benefit each other, making as a result a positive correlation. Considering the political individuals' subjectivity, Gao Zhengang stated in 2012 that "the establishment of individuals' subjective position is a must for the realization of political civilization, the liberation of human beings and the prerequisite of attaining subjectivity. In a word, political subjectivity is the political self-consciousness, self-dependence and creativity displayed by the political subjective in political life." when he was doing a research on the evolutionary change and logical structure of political subjectivity. The real ethical purpose and pursuit of CPC which represents the interests and benefits of all the Chinese people, is to realize and maintain the fundamental interests and benefits of all the Chinese people, protect the subjective positions of different interest groups, rally the enthusiasm, initiative and creativity of all the Chinese people, and give full play to the political subjectivity and enthusiasm of the Chinese people. In the report at the $18^{\text {th }}$ Party Congress, Mr. Hu Jintao, the former president of China, called that "the Party will protect the subjective position of its members, better protect their democratic rights, conduct criticism and self-criticism, foster comradely relations based on equality and democratic principles, a political atmosphere that encourages democratic discussion, and an institutional environment for democratic oversight, ensure that its members have the right to stay informed of, participate in and oversee Party affairs, as well as the right to vote." which certainly includes the protection of the subjective position of rural Party members.

The protection of the subjective position of rural Party members who are the main force of the work in rural areas and the building of community-level Party organizations in rural areas in the new historical period, can be realized by making the Party members in these areas have the sense of benefit, satisfaction and happiness as a Party member through providing them with material and spiritual supports and perfecting the institutional mechanism of the community-level Party organizations where they work, which can accordingly increase their recognition of, participation in and self-contribution to the Party's policies in rural areas. The essence of the subjective position of rural Party members can be understood from the perspectives of the power the Party members enjoy, their behaviors and wills based on governing ethics. In terms of power, the rural Party members 
have the right to criticize and advise the work of the village and the Party, the right of being informed of and participating in the key issues and decision-making process of the villages, the right to vote the leaders in the village Party organizations and oversee their work, the right to get help from the Party organizations when they have difficulties in production and life, etc. In terms of behavior, they have a comradely relation based on equality and democratic principles with no difference between the community-level Party members and their leaders, they take an active role to participate in the decision-making processes of the community-level Party organizations, they usually become the vanguards and role models in the production activities, promotion of folk customs and life styles in accordance with the Party Constitution, and they often take the lead to change the prevailing habits and customs and resist the still remaining feudal and superstitious beliefs in the rural areas and advocate the historically accumulated good qualities of kindness and honesty of farmers, about which, Zhu Linjun claimed in 2006 that "intra-Party democracy has an exemplary effect in society, which can promote the development of social democracy, and enrich the relationship between Party and people." when he was doing a research on Party and people. In terms of will, they have the responsibility to build a political atmosphere based on harmony, democracy and equality, and they have the freedom to express their desires and demands based on their wills which should not be affected by any force.

\section{The Awkward Circumstance Formed by the Weakening of the Community-Level Party Organizations in Rural Areas from the Perspective of Governing Ethics}

In recent years, the living conditions, health care and social security systems in rural areas have taken a great step up with the development of the building of new socialist rural areas. Notable progress have been made by the community-level Party organizations in rural areas in accordance with the call of the Party in the protection and implementation of the rights of rural Party members, the development of intra-Party democracy, the increasing support to rural Party members, etc. which have generally aroused the subjective awareness of rural Party members. However, these improvements have brought new challenges to the building of community-level Party organizations by enriching them though, due to the fact that China now is going through a fundamental period when the economical institution, social structure, interest pattern, and people's views and values are critically changing. The rights of farmers to dispose of their money indeed have expanded and the economical basis in rural areas have changed notably, but the rural Party organizations are at the same time facing an awkward situation and have to choose to reposition, since they have lost their manipulating position as it was in the period of collective economy. The awareness of democracy of farmers have also been increasing, which so pushes the community-level Party organizations to adopt new methods in their way of leading. In a nut shell, the fact that the community-level Party organizations have weakened can't be ignored.

Although the causes for the weakening of subjective position of rural Party members are complicated due to the vast territory of China and the differences in natural, economical and cultural environments, and folk customs in its rural areas, this research has found out three shared though different in degree causes on the problem of the weakening of rural Party organizations after a lot of field researches as follows:

Firstly, rural Party members at the community-level Party organizations though critically important in the development of rural economy and in the process of Party-member leading people to get rich in the rural areas, have weakened the scope of the administration of the community-level Party organizations since most of them went to join the floating population. In recent years, most of the rural Party members have become migrant workers or went into business, which makes some of them have weak sense of Party spirit, ignore the organizational principle of the Party, and unwilling to report to the Party organizations in their native places. Some of the Party members gradually losing their awareness as a Party member and becoming indifferent to the organizational activities of the Party, often neither attend the local organizational activities of the Party nor report to the Party organizations in their native places, which makes the supervising work of the Party organizations in their native places difficult and impossible on the other hand for the local Party organizations. Some Party members in the floating population stay out of the Party organizations by concealing their Party identity and so become "recessive Party members" or "archive Party members" with no supervision by the Party organizations. However, this awkwardness should be attributed to the administration of the community-level Party organizations. Some of the community-level Party organizations whose Party members floating out didn't carry out the administrative measures of the Party on the floating Party members, resulting in the zero attendance of the latter to organizational activities and ideological education of the Party. Some of them didn't issue "the certificate for floating Party members" or "Party member certificate" to the floating Party members, while the Party organizations where the Party members floating into didn't check the "floating Party member certificate" seriously, which together make the administration of Party members with "the floating Party member certificate" ineffective. All these above have made the education and administration of Party members difficult and even 
have some Party members stay out of the Party organizations. So it is clear enough that the administration and education of Party members based on their native Party organizations without considering their professions and ages have been restricting the personal development of Party members and weakening the cohesiveness of the Party gradually.

Secondly, the pan-market phenomenon in the whole society has weakened the subjective position of rural Party members to a large degree. Since the adoption of the policy of reform and opening up in 1978, the promotion of market to economy of the whole society has been highly recognized with the rapid development of market economy, which has made the idea of socialist market economy deeply rooted in the hearts of Chinese people. But this doesn't mean that market is all good. The pan-market phenomenon in the whole society is really not good because it has weakened the subjective position of rural Party members.

Pan-market phenomenon occurs in the following three aspects: first, infinite exaggeration of the effect of market, which believes that market is omnipotent, market mechanism can solve all the problems, and any state administration and regulation is the negation of market economy. Second, the over-application of the principle of exchange based on equality of the market to all sectors of the society, which makes all the sectors related to people's life market-oriented, including some originally should not be commoditized affairs and some originally should not be made market-oriented social sectors, as Graham Wallas wrote in his book "Humanism in Politics" that "almost all the socialist and personal economical problems have become a matter of property." Third, the alienation of power, which depicts the phenomenon of the pursuit and exercise of power by some politicians based on the principle of market while those politicians who are really conscientious and committed to their work are despised to be out-of-date.

The pan-market effect on the weakening of the subjective position of rural Party members can be seen clearly in the following two cases. Case one, some Party members under the influence of pan-market effect believing that the participation in the Party activities can't bring them practical benefits, so often escape from such activities or don't take it seriously even though they participate sometime. Case two, some Party leaders who got elected with bribery are keen on the absolute control of power and meet their personal desires at the expense of the interests of the villagers, which usually causes conflicts between the villagers and the community-level Party organizations and seriously affects the latter's work because some of the misconducts of the Party leaders in the rural areas can't be handled properly in time.

Thirdly, the hollowing condition in the rural areas makes the object or people of the community-level Party organizations disappear. The cause of the hollowing condition is urbanization which means the aggregation of population and working forces in the urban areas, the agricultural industry continuously transferring into non-agricultural industry, and the gradual transforming of rural living style into urban living style. This kind of change has divided the people in rural areas into two groups based on the villagers' personal interests and benefits and living habits since the process is totally unnatural. The first group is constituted by those who still stay or are left behind in the rural areas. These people hold resistant attitudes towards the urbanization and usually don't support, respond to the community-level Party organizations in the work of policy evaluations and the reforms of property rights system because the lack of sense of trust to and recognition of the community-level Party organizations, which seriously affects and hinders the process of urbanization. The second group refers to those young and strong people who go out to be migrant workers, which accordingly causes the phenomena such as absence of working force, financial outflow, vacancies of houses, idleness of land, old people and children left behind, etc. in rural areas. As a result, some community-level Party organizations in rural areas, especially those in remote rural areas, can't operate normally because the aging of their members and the lack of people in production activities and other activities due to the outflow of people.

The above problems occurred in the building of community-level Party organizations should be taken seriously. Speaking from the perspective of governing ethics, the weakening phenomenon should be handled with responding strengthening strategies which certainly is not equal to compulsory measures. The characteristic of governing ethics is to educate and guide people flexibly, by doing which, the first thing is to let the Party members in rural areas recognize that farmers can only display their talents into full in rural areas. Honestly speaking, migrant workers have contributed a lot to city constructions, but the rewards they got on the other hand are small. And if the logic of farmers who stay in rural areas can display their talents into full and so earn more is true, the Party members at the community-level Party organizations would better perform their subjectivity as Party members and make a great difference to the modern agriculture of China with the farmers under their leadership. 


\section{Ways to Protect the Subjective Position of Rural Party Members in the Building of Governing Ethics}

The building of governing ethics relies on the continuous protection of the subjective position of Party members in making decisions and doing business, and rallying the enthusiasm, initiative and creativity of the Party members by showing whom humanistic care through each community-level Party organization. That is to say, the building of governing ethics should focus on the building of the community-level Party organizations by gradually setting up an overall system of protection mechanisms, namely, contact and care mechanism for the floating rural Party members, the support mechanism for rural Party members who have difficulties, the mechanism for educating and disqualifying rural Party members who are not qualified any more, the effective operation mechanism of the activities of the rural Party organizations, and the multiple financing mechanism for the activity funds of the rural Party organizations. If these are all realized, the subjective position of rural Party members can be protected.

The community-level Party organizations whose building is key for all the work of the Party are responsible for the close contact with and organization of people, and implementing the Party's line, principles, and policies. They are also the core of leadership for all the organizations and work in rural areas. The building of the rural Party branches is significant to speed up the development of rural areas and is the hope for farmers to get rich and the modernization of rural areas. The key of the building of rural Party branches lies in the elections of the Party branches' secretaries who must be impartial and honest, young and strong, bold enough to think and act, willing to endure hardship and contribute, and able to lead people to get rich. Besides, the building of community-level Party organizations should integrate the institutional building and the conduct of the Party members so as to establish a good reputation of the community-level Party organizations.

The specific illustrations to the five mechanisms to protect the subjective position of rural Party members are as follows:

\section{1) The establishment of contact and care mechanism for floating rural Party members}

Each village should establish personal archives for floating Party members, and if possible, the corresponding electronic archives should be established, too. The members of the village Party organizations are responsible for the administration of the archives of Party members, which should be done in a systematic and standard way through establishing and perfecting the rules and regulations for the query, transfer, update, confidentiality, etc. of the archives of the Party members. A member in each community-level Party organization should be specifically responsible for the recordings of the floating in and out of Party members, assuring that Party members are floating but disappearing. The same Party organization member or a different one in each community-level Party organization should be responsible for asking the opinions and advice of their floating members by making calls or sending messages about some key issues such as the elections of Party leaders and Party representatives, land expropriations and housing demolitions, the allocations of relief funds, the evaluations of the availability of some people of the basic living allowances, etc, of their village. Each village Party organization should also organize their remaining members to visit the families of the floating Party members and provide certain help for those families who have difficulties in life, making the floating Party members feel the care and warmth from the Party, and if necessary, encourage and lead the floating Party members return to hometown and start their own businesses to repay their hometown.

2) The establishment of support mechanism for rural Party members who have difficulties in their lives

The establishment of a scientific and standard system is key to the intra-Party encouragement and support work, which should be carried out by gradually perfecting the system for helping Party members who have difficulties in their lives and other difficulties they face in production and life so as to ignite their senses of pride, honor and mission. Mao Tse-tung as the representative of the first generation of leaders of the CPC also paid much attention to Party members who had difficulties. He said: "We should take good care of the Party carders and their families if they have diseases or difficulties in their lives." The support to Party members who have difficulties in their lives can be a long-term strategy if those community-level Party organizations could set up intra-Party care or support funds and organize other intra-Party activities of relief.

3) The establishment of the mechanism for educating and disqualifying Party members who are not qualified any more

Currently, China is going through a critical period in terms of the development of agriculture and rural economy, which has derived a series of new problems, conflicts and challenges with the emergence of new rural areas, new farmers, and new generation of migrant workers. Some of the rural Party members might become corrupt and degenerate without proper education and administration in face of such new things. Thus, the education of the 
rural Party members should be carried out in a systematic, standard and periodical way and the form of education should be diverse. The community-level Party organizations should warn and remind in time the Party members who have the tendency to be corrupt and offend the Party rules and regulations. For those who have been repeatedly educated and warned but still have no attempt to change, it is necessary to disqualify them from the Party by setting up an evaluation system based on the practical conditions in the rural areas in accordance with the Party Constitution, assuring that the evaluation and disqualifying of the unqualified Party members have authoritative basis which are adaptable and applicable to all the other unqualified Party members. Marx and Engels had pointed out when they built the Communist League that "anyone who conducts misbehaviors or offends the rules of the League should leave or be disqualified from the League according to the seriousness of the case. And the disqualified will never be accepted again into the League."

\section{4) The establishment of effective operation mechanism for the activities of rural Party members}

The community-level Party organizations should establish the long-term mechanism for carrying out activities by making the operations of the Party transparent, seek advice from people with focus on those things that closely related to people's lives, such as the development of modern agriculture, the cultivating of new farmers, the leading of people to get rich, and the promoting of income increases of farmers, the building of new rural areas, the infra-structure construction, etc. The community-level Party organizations should do something useful and good or some projects each year for the rural areas under their respective jurisdictions based on the following three aspects: the first is the decision-making based on democracy by consulting people on governance, learning about their needs, seeking their advice, and taking different forms to ask for their opinions, so as to ensure that the planned projects can reflect people's actual demands, be welcomed by people, and can benefit them. The second is the steady perfection of service content with the standardization of serving ways, improvement of serving ability, and the encouraging of Party members to be vanguards and models in serving people by letting them participate in voluntary activities, setting up Party member volunteer teams, letting them make and fulfill promises, etc. The third is the constant development and expansion of Party membership by focusing on the building of Party membership, insuring that the community-level Party organizations have qualified successors.

\section{5) The establishment of a multiple financing mechanism for the activity funds of rural Party organizations}

Without the protection funds, the scientific building of community-level Party organizations can't realize, the subjective position of Party members can't be protected effectively, and the enthusiasm of people handling Party affairs will be affected. In order to guarantee the availability of funds, efficiency and fruit-bearing of the building of Party organizations, the community-level Party organizations should establish a multiple financing mechanism for activity funds by further emancipating their own minds. They should ensure that the funds allocated by the upper Party organizations are used in key projects, raise funds from social sponsors by ensuring that the funds are all used on the building of Party organizations and the subjective position of rural Party members are protected, increase the total amount of Party membership dues by encouraging outstanding or financially capable Party members to pay extra-dues as special funds. And community-level Party organizations in the under-developed rural areas should cooperate with those community-level Party organizations which have got rich first by learning their experience and getting help from them.

\section{Conclusion}

The adoption of the policy of rule of virtue by the CPC in state governance, demonstrates its high recognition of the flexibility effect of governing ethics in the modernization process of the system and capability of the governance of the Party and the state. Like all the other governors throughout the Chinese history, the CPC though puts the issues related to agriculture which plays a key role in the livelihood of everyone, rural areas where people are simple and honest, and farmers who got a reputation of being industrious and kind, at a key position, it can't prevent the subjective position of rural Party members from being weakened with the negative effect of the pan-market phenomenon in the society due to the unique cultural background of rural areas and life style of farmers.

The essence of Party organizations determines that they have to localize their function on quickly and completely transferring the wills and demands of people by establishing smooth interactional mechanism with them. They should manage to make farmers and Party members in rural areas realize that they can only play their talents into full through engaging in agriculture in rural areas by educating and guiding them and protect the subjective position of Party members in rural areas in order to consolidate the basis of the community-level Party organizations by establishing multiple protection mechanisms.

In terms of the modernization of governance, the community-level Party organizations should build the 
following mechanisms: a law-based social governance system featuring Party committee leadership, government execution, nongovernmental support and public participation. In order to make the building of Party organizations in rural areas a regular and long-term goal, the community-level Party organizations should on the one hand make long-term plans and short-term goals for intensifying the building of rural Party organizations based on specific conditions, and promote the building of the community-level Party organizations as a whole by realizing the short-term goals successfully under the guidance of long-term plans. On the other hand, they should standardize the work in the Party by perfecting its system. The systematic building which needs to consider the whole situation and long-term effect should be fundamental and steady, the establishment, improvement and perfection of which will surely make the theories and practices of community-level Party organizations become systematic and standard, and the rural areas more harmonious, civilized, and prosperous.

\section{References}

(1979). Complete Works of Marx \& Engels (Vol. 42). Beijing: People's Publishing House.

(1991). Selected Works of Mao Tse-tung (Vol. 2). Beijing: People's Publishing House.

(2012). Firmly March on the Path of Socialism with Chinese Characteristics and Strive to Complete the Building of a Moderately Prosperous Society in all Respects. People's Publishing House.

Gao, Z. G. (2012). Research on the Evolutionary Development and Logical Structure of Political Subjectivity. The Journal of Humanities, (5).

Graham, W., \& Li, H. Z. (2006). Humanity in Politics. Nanjing: Jiangsu Education Publishing House.

Zhu, L. J. (2006). Consistency and Conflicts: Rethinking on the Relationship between Party and People. People's Publishing House.

\section{Copyrights}

Copyright for this article is retained by the author(s), with first publication rights granted to the journal.

This is an open-access article distributed under the terms and conditions of the Creative Commons Attribution license (http://creativecommons.org/licenses/by/4.0/). 